\title{
THE RUSSIAN FAR EAST IN A POST COLD WAR ENVIRONMENT AND NEW INTERNATIONAL COOPERATION PLANS
}

\section{Sergey Sevastyanov}

Last 10 years of the so-called market reforms hit the Russian Far East (RFE) extremely hard. The crisis of the reforms manifested itself by negative consequences in all spheres of people's life (economics, security, social standards, etc.). As a result of it, President Paten's idea to establish more efficient state power system in Russia, as well as some other reforms proposed by him enjoyed strong support of the RFE's population. That is why; in the first part of my article I will elaborate on how Yeltsin reforms influenced economics of the RFE, and why their consequences were mostly negative.

Secondly, I will explore first initiatives proposed by the new Russian President Vladimir Putting for the revival of the RFE, and then I will try to find out what role international economic cooperation projects may play to complement these new plans.

\section{Contemporary Socioeconomic Situation}

You may well know that for a long historic period (from 1930s till 1990s); one of the purposes of the centrally planned economy of Russia was to build up a military power in the Pacific. To achieve that goal, great economic and financial resources and subsidies were pouring into the region constantly, while about $50 \%$ of the gross industrial output was that of military character.

Gorbachev's peaceful initiatives first hit local engineering industry, especially military industrial complex (MIC) in the late 80-s. In 1992 Yeltsin's government stopped all subsidies for the RFE (transport, energy, wages, etc.). As a result of it, the region lost the Russian domestic market due to a decrease in general demand. and very soon the socioeconomic situation in the RFE has changed radically to the negative. Since 1991 the Russian military production declined dramatically, as state orders for production of weapons and military equipment were reduced till the year 1995 by more than 90\%. From 1991 till 1995 the RFE industrial output in all sectors declined about $58 \%$ due to the fact that the domestic market of the RFE itself was too small to support demand effectively. In 1996, a new federal program was proposed for the economic and social development of the RFE and Zabaykalye for the years 1996-2005. The main idea 
of the program was to integrate the RFE with the Northeast Asian market, and at the same time, to place the RFE within a framework of the Russian Federation's domestic division of labor. However, very few practical steps were being taken to help the region to date.

The RF Government's non-interference in the RFE economic processes led to a drop in practically all economic activities in the region, and subsequent decline in living standards there. Per capita income in Maritime province in 1999 accounted-for about $80 \%$ of the average Russian income, and it was 4.5 times lower than in Moscow. In most part of the other RFE provinces per capita income was even lower than in Maritime province. Such processes resulted in the massive outflow of population from the RFE. From 1991 till 1998 more than one million people left it (RFE population is about 7 million now), and moved to the central part of Russia.

During reforms' years the most critical task for the RFE provincial administrations was to help military industrial complex (MIC) enterprises to convert its production. It was very hard to do, because Moscow practically did not allocate money for conversion programs. However, the year 1998 became a stabilizing one for some of the RFE MIC enterprises due to the following factors: effective production diversification effort, strong local government support, and August-98 drastic change in the ruble to dollar ratio.

For the last several years Maritime province administration was able to launch a number of conversion programs using local MIC capacity to build small and medium size fishery-boats, and to construct agriculture machinery.

However, to get well-paid state .orders to produce armament for foreign countries is still the easiest way for local MIC enterprises to survive. Considering Russian foreign policy in Asia, it was quite natural for Moscow to pay special attention to China, Korea, and Japan.

China has continued to be the main focus of it. Between 1991 and 1997, Russia sold China armaments worth more than U.S. \$6 billion. A very important agreement for further increasing the level of military and technical cooperation was achieved in 1999, as result of it for the next five years (2000-2005) the overall value of the Russian arms exports to China are projected to be U.S. \$5-6 billion.

In such a situation military sales to China have become critically important for the survival of the RFE MIC. Su-27 fighters, "Musket" anti's hip missiles are produced here; besides Zvezda has secured an order to repair Chinese Kiloclass submarines. Consequently, this arms sales dependence is becoming dual: China depends on Russian military technology, while the RFE depends on Chi- 
nese money to sustain its MIC, at least for the next four-five years. So, on the whole, for the foreseeable future, Russia can only be expected to maintain close ties with China. However, if the RFE will not be able to overcome its long-lasting economic crisis, in the long run, the geopolitical tendencies in this bilateral relationship may work against Russia.

For many years the Russian-Japanese relationship has been characterized by obvious controversy. On one hand, the geopolitical interest of both countries rests with the radical improvement of bilateral relations. On the other hand, the Russian side has continued to emphasize the idea of a joint economic exploitation of the Northern Territories area, without the transfer of sovereignty. Japan was not agreed to accept such a proposal, and their negative position has been demonstrated again during recent visit of the Russian President to Tokyo.

To improve bilateral relationship with North Korea, in February 2000 the RF Minister of Foreign Affairs Igor Ivan made an official visit to-Pyongyang, and signed a new bilateral treaty on cooperation and friendship. It was a serious breakthrough in bilateral relationships. In future Russia would try to do its best to secure full- scale participation in dealing with Korean Peninsula's problems, and to maintain balanced relationship with both Koreas.

Another important issue, one might mention for better understanding of the socioeconomic situation at the RFE, is a federal debts' problem. For several years the RF Armed Forces, including both Far Eastern Military District and Pacific Fleet, terribly suffered from the lack of adequate finance. A considerable part of that burden was put on the RFE provinces' budgets. They supplied the Armed Forces and other federal structures' units with electricity, fuel, food, etc., while the RF Government was paying only part of that money.

Lack of adequate finance also made it more difficult to support decommissioned nuclear submarines' dismantlement, and nuclear wastes processing' safety issue. Both problems are extremely urgent for the Pacific Fleet, which has a lot of decommissioned submarines waiting for full dismantlement, and nuclear reactors' deactivation. Substantial nuclear wastes' stocks at Bolshoi Kamen are also ready to be processed. USA and Japan were already allocating money to fix the problem, and that effort has become a very important area of international cooperation.

So, I have mentioned only several critical features of the RFE economic and security landscape to demonstrate that if not making a radical change in its economic and social policy towards this region, Moscow could not sustain it. 


\section{Proposed Reforms and International Cooperation Projects}

With a new President after 10 years of Boris Yeltsin, we may expect new policies from Moscow toward the RFE. In his first Address to the RF Federal Assembly in July, 2000, Vladimir Putin proposed that strengthening a federal component of executive power was the only practical way to implement any reforms in such a large country as Russia.

The Russian budget 2001 project demonstrated that the RF military budget would be increased to about 206 billion rubles (it is roughly $3 \%$ of GDP). It was good news, because such a modest increase could help to sustain the RFE Armed Forces in a more adequate shape, and also to decrease financial pressure on the local provincial budgets to support RFE federal units. In July, 2000 Putting declared some new Russian approaches to its Asian policy.

First of all, he clearly expressed his strong dissatisfaction with the present socioeconomic situation at the RFE, and demonstrated his willingness to improve the situation. It was a sea change in formulating Russian internal policy goals, because former President Boris Yeltsin had never given much consideration to that region.

Secondly, Putting declared that Russia was both European and Asian state, and that was why Russian foreign policy would be balanced. During Russian President's visit to China (July 18-19), both countries confirmed their course for strategic partnership* Presidents agreed to further develop cooperation in a number of joint economic projects, to increase Russian arms sales to China and to deepen border trade. Considering Paten's visit to DPRK, it became a real breakthrough in bilateral relationship, Both Presidents discussed economic cooperation, bilateral trade, and other issues, but the most sensitive topic was the situation with North Korean long-range missiles program.

On July 21 Putting met with the RFE leadership in Blagovescensk. At that meeting he ascertained that during last years those two regions were developing at extremely low tempo, and that perspective development of the RFE and Zabaikalye became of critical and even dramatic importance for Russia. He declared that Russia must fundamentally change its policy toward the RFE to convert this region, which possesses abundant natural resources and high industrial potential, into a prosperous part of the country. He claimed that the most urgent matter was to convert the region from a group of divided territories into a joint complimentary system.

To start moving towards that ambitious aim he set two principal tasks:

- The task for the RF Government was to elaborate a concept That should define several principal projects for concentrated Federal money allo- 
cation in order to change the whole RFE Economies' operational mode for a more positive one;

- The task for the RFE President's Representative (RFEPR) General Constantine Pulikovsky was to lead the efficient inclusion of the RFE into a joint federal system.

Blagovescensk meeting has clarified the future role that President's Representative would play in the region. For a few months it changed from just exercising control over Governors' policy to assuming full responsibility for the RFE.

A few days after the meeting Pulikovsky began to form the RFE Federal District Council. RFE Governors, provincial Duma's Chairpersons and federal (Ministry of Defense, Ministry of Interior, etc.) structures' leaders would be its members. That Council would become a regional-level branch of the executive power with its decisions binding for all RFE provinces. At July 25, 2000 Putin took part in one more RFE Conference (in Petropavlovsk-Kamchatski), which was devoted to the most urgent social economic problems. In fact, just during two months Vladimir Putting took part in three Conferences in the RFE (Blagovescensk, Kamchatka and Sakhalin) to discuss its economic situation. In his address at Petropavlovsk-Kamchatski President clarified the most important RFE industrial spheres and special objects for preferential federal money allocation as follows:

- Bureyskaya hydroelectric power station's completion;

- Oil and gas extraction projects at the shelf of Sakhalin island;

- Gas pipelines' construction in Maritime and Khabarovsky provinces;

- Exploitation of prospective coal-fields;

\section{Development of the regional infrastructure}

In September 2000 the RF Government, Federation Soviet, and the RFE leadership came to Irrupts for the Baikal Economic Forum to elaborate a joint Concept for the development of two federal regions (RFE and Siberia). That Concept has got a working title as follows: "Russian Asia-Pacific Strategy for the 21 st Century". It should propose appropriate measures to support favorable investment climate, customs preferential duties, to form the Russian Asian Bank, to realize a number of infrastructure development projects, etc.

It is worth to note here that an influential Moscow politician Sergey Saccharin in recent interview bravely proposed to launch a long-term program, which may be called "A Great Resettlement". He even elaborated that an idea to 
save the RFE and Siberia could well become a new national idea, which Russia was actively searching for.

It is amazing, how similar may be strategic challenges facing Russia and China. One of the main topics at the plenary session of the Central Committee of the Chinese Communist Party in October 2000 was to plan large-scale developments in the western regions of the country to level the socioeconomic gap between the coastal and interior regions.

The RFEFR General Pulikovsky recently declared that too high tariffs for electricity, air- and railway transportation were effectively cutting off the RFE from other parts of Russia. To solve energy shortage's problem he proposed to speed up completion of the Bureyskaya hydroelectric power station (the first section of it is to become operational in two years). To improve transportation system he suggested building a highway connecting Siberia and the RFE (he recommended to begin highway construction in Chitinskaya province).

Comparing Baikal Economic Forum's agenda, Sergey Saccharin's proposals, and the RFEPR recommendations, one may arrive at a conclusion, that all of them were introducing a new idea to elaborate a program for the joint development of the RFE and Siberia.

Two regions have strong similarities (vast under populated territories, abundant natural resources, strong MIC component, and an economic bent for Asia). Their economics are partly complementary, thus making a good basis to increase interregional trade volume. Besides, interregional transportation tariffs may be relatively low (in comparison with tariffs between the RFE and central part of Russia).

So, it may be easier and more efficient for the RF Government to control these two vast regions as a joint system, while Siberia may play a role of'economic glue", not allowing the RFE to secede from Russia economically.

During Vladimir Putin's Asian trip in July, 2000, his most favorable economic topic was bilateral and multilateral energy cooperation programs. Energy supply sources' security and Middle East oil dependence became a critical problem for Japan, RK, and recently for China. Fortunately, their neighbors (the RFE and Siberia) have abundant resources of oil and gas. China was ready to buy Russian oil and gas, but the devil, as always, was in the details. Moscow did not come to an agreement with Peking yet on the annual quantities of oil and gas to be delivered to China. 20 billion cubic meter of gas and 16 million tons of oil delivered annually was not enough for Russia to make profit. Besides, Peking did not agree to lay oil and gas pipelines through the territory of Mongolia. They prefer to go directly from Russia to the Northeast part of China. 
To achieve compromise, both countries face a perspective to coordinate their regional development and energy cooperation plans between Russia (Eastern Siberia and the RFE) and China (Western and Northeast parts of the country). Recent changes in the situation on the Korean Peninsula are considered in Russia as an omen of favorable economic cooperation opportunities. Firstly, Moscow is planning to reestablish its close economic and trade ties with Pyongyang. Northern Korea and the RFE economics are complementary. Besides, Moscow is a strong contender to help Pyongyang in reconstruction of its industrial and infrastructure objects, because most of them were built with Russian assistance. Furthermore, Russia would like to become a member of the International Consortium for the DPRK Economic Revival (the idea to form such an organization is given consideration now).

Secondly, Russia is eager to extend its Tran Siberian railway to South Korea. What is more in October 2000 the RF Premier-Minister Kasyanov proposed to his Korean counterpart Russian help with reconstruction of 500 kilometers of railway at the territory of Northern Korea? Future exploitation of this world longest transnational railway would let South Korea and some other Asian countries to cut by half cargo transportation period from Asia to Europe (15-17 days by railway in comparison to 35-40 days by sea), and substantially decrease transportation costs. Russia and DPRK would get much more profit for the transit of increased amount of containers.

Last but not the least is the possibility for Russia to use the whole Korean territory to lay gas pipelines to the RK, and later to Japan, and /or to eastern China (all these countries need to increase the portion of gas in their national energy balances).

Japan is also considered by Russia as a very prospective partner. During his recent September visit to Tokyo President Putting proposed a joint grand plan to extend the Tran Siberian railway to Japan. It incorporates an idea of a joint construction of the two tunnels: between the Russian main land and Sakhalin island, and between Sakhalin and Hokkaido. Joint use of this extended Tran Siberian railroad would help Tokyo to decrease three times its cargo transportation period to European countries, and also would make Russian natural resources' transportation to Japan much more efficient. Paten's second proposal, also aimed at developing regional economic integration, was to build up an energy bridge between the two countries. He proposed Japanese businessmen to participate more actively in the Eastern Siberia, and Sakhalin Island's gas and oil extraction and transportation projects. 
The RFE is actively participating in a number of other multilateral economic cooperation projects, including the East by West Corridor, and the Truman River Area Development Program (TRADP). Russian approach to the Truman Program is based in the broad context of developing Maritime province, and the RFE as the whole. Only about $50 \%$ of the Maritime Province's transportation complex capacity is used now. However, some of these seaports need renovation. That is why Russia has put forward several infrastructure development projects conducive to establishing convenient trade routes between Northeast China and American West Coast-through the ports and railways of the Maritime province. Considering TRADP environmental concerns, Russia proposed to use its Vladivostok research institutes* capabilities to create an international system for ecological monitoring of the whole TRADP area. Besides, Maritime province administration proposed to TRADP leadership to form Vladivostok investments' Center to serve as a source of information for foreign investors.

Recent political changes in Asia are creating favorable basis for multilateral cooperation, especially in energy and infrastructure development projects. In fact, multilateral approach in developing and delivering Russian gas to the users in Russia and beyond its borders is the only practical solution (funds should be mobilized mostly through foreign investors). That is why; peaceful Dark's economic engagement is of critical importance to Russia, otherwise most part of the Northeast Asia energy community and extended Tran Siberian railroad multilateral projects have very few practical chances to be materialized.

\section{The List of Selected Bibliography}

1. Asia-Pacific Security Outlook, 1997, East-West Center, Honolulu, Hawai

2. 2000 Russian Foreign Policy Concept

3. "Vladivostok" (July 12, August 15,2000)

4. "Rossiiskaya gazeta" (July 22, August 3, August 8, August 18, 2000)

5. “Argumenti I fact"(August $\# 31,2000$ )

6. "Krasnoyarsk zed" (July 25,2000) 